\title{
C-reactive Protein to Albumin Ratio as A Novel Inflammatory Biomarker for Postoperative Delirium in Patients Undergoing Transcatheter Aortic Valve Replacement
}

\section{Transkateter Aort Kapak Replasmanı Uygulanan Hastalarda Postoperatif Deliryum için Yeni Bir Enflamatuvar Biyobelirteç Olarak C-reaktif Protein/Albümin Oranı}

\author{
๑ Muhsin Kalyoncuoğlu, ๑ Halil ibrahim Biter, ๑ Gündüz Durmuş, ๑ Birgül Baştan*, \\ - Mehmet Mustafa Can \\ University of Health Sciences Turkey, Haseki Training and Research Hospital, Clinic of Cardiology, Istanbul, Turkey \\ *University of Health Sciences Turkey, Haseki Training and Research Hospital, Clinic of Neurology, Istanbul, Turkey
}

Abstract

\begin{abstract}
Aim: We aimed to investigate whether C-reactive protein-toalbumin ratio (CAR) predicts postoperative delirium (POD) development in patients undergoing transcatheter aortic valve replacement (TAVR) procedure.
\end{abstract}

Methods: Data of 78 patients with the mean age of $76.3 \pm 8.4$ years, who underwent TAVR, were retrospectively analyzed. The CAR, neurophil-to-lymphocyte ratio and platelet-to-lymphocyte ratio values were calculated in all patients. Presence of delirium was determined by using the Richmond Agitation-sedation scale and the Confusion Assessment Method for the Intensive Care Unit.

Results: As compared with the nondelirious group, delirious patients had significantly higher EuroSCORE II $(p=0.03)$ and TAVR score $(p=0.009)$ and more frequent major bleeding $(p=0.005)$, major vascular complications $(p=0.018)$ and acute kidney injury (AKI) $(p=0.002)$. The main independent predictors of POD were CAR value $(p=0.02)$, AKI $(p=0.02)$, major bleeding $(p=0.005)$, and TAVR score $(p=0.04)$. The area under the curve of CAR for POD development was 0.718 (95\% confidence interval: $0.605-0.814 ; p=0.002$ ) with $82 \%$ sensitivity and $56 \%$ specificity.

Conclusion: CAR is a promising inflammatory parameter in predicting POD and may help identify subgroups of individuals at risk for POD.

Keywords: Transcatheter aortic valve replacement, inflammation, C-reactive protein, serum albumin, delirium
Öz

Amaç: Transkateter aort kapak replasmanı (TAVR) uygulanan hastalarda C-reaktif protein albumin oranının (CAO) postoperative deliryum (POD) gelişimini tahmin edip etmediğini araştırmayı amaçladık.

Yöntemler: TAVR uygulanan 78 hastanın (yaş ortalaması: $76,3 \pm 8,4$ yıl) verileri retrospektif olarak incelendi. Tüm hastaların $\mathrm{CAO}$, nörofil lenfosit oranı ve trombosit/lenfosit oranı değerleri hesaplandı. Deliryum varlı̆ı̆, Richmond Ajitasyon-Sedasyon skalası ve Yoğun Bakım Ünitesi skalası için Konfüzyon Değerlendirme Yöntemi skalası kullanılarak değerlendirildi.

Bulgular: Deliryum olmayan grupla karşılaştıııldığında, POD hastaları anlamlı derecede daha yüksek Euroscore ॥ $(p=0,03)$ ve TAVR skorlarına $(p=0,009)$ sahip idi. POD hastalarında daha sık majör kanama $(p=0,005)$, majör vasküler komplikasyonlar $(p=0,018)$ ve akut böbrek hasarı $(A B H)$ geliştiği gözlemlendi $(p=0,002)$. CAO değeri $(p=0,02), A B H(p=0,02)$, major kanama $(p=0,005)$ ve TAVR skoru $(p=0,04)$ POD gelişiminin bağımsız öngördürüleri idi. POD gelişimi için CAO eğrisi altındaki alan \%82 duyarlıık ve \%56 özgüllük ile 0,718 (\%95 güven aralı̆̆ı: 0,6050,$814 ; p=0,002$ ) olarak bulundu.

Sonuç: CAO, POD'yi tahmin etmede umut verici bir enflamatuvar parameter olup POD riski taşıyan bireylerin identifiye edilmesine yardımcı olabilir.

Anahtar Sözcükler: Transkatater aort kapak replasmanı, enflamasyon, C-reaktif protein, serum albümin, deliryum
Address for Correspondence/Yazışma Adresi: Muhsin Kalyoncuoğlu, University of Health Sciences of Turkey, Haseki Training and Research Hospital, Clinic of Cardiology, İstanbul, Turkey Phone: +90 2125315947 E-mail: mkalyoncuoglu80@gmail.com ORCID: orcid.org/0000-0002-6552-0942 Received/Geliş Tarihi: 08 October 2019 Accepted/Kabul Tarihi: 10 February 2020
${ }^{-}$Copyright 2020 by The Medical Bulletin of istanbul Haseki Training and Research Hospital The Medical Bulletin of Haseki published by Galenos Yayinevi. ${ }^{8}$ Telif Hakkı 2020 istanbul Haseki Eğtitim ve Araştırma Hastanesi Haseki Tip Bülteni, Galenos Yayinevi tarafindan yayınlanmıştr. 


\section{Introduction}

Nowadays, transcatheter aortic valve replacement (TAVR) has emerged as an alternative to surgical aortic valve replacement (SAVR) for the treatment of patients with symptomatic severe calcific aortic valve disease (CAVD) who are not candidates for surgery or who are considered to be at a high surgical risk (1). Delirium is a neuropsychiatric behavioural syndrome characterised by acute changes and fluctuations in attention, thinking, and consciousness (2,3). Postoperative delirium (POD) is frequently observed after TAVR and proposed to be associated with several adverse outcomes including prolonged hospital stay, readmission, and mortality after TAVR (3). Since it is an important source of clinical concern, attempting to determine independent risk factors for POD and establishing an early diagnosis are of great importance in improving the outcome.

Despite the knowledge about the epidemiology of POD, its pathophysiology remains unclear. Inflammation is one of the various proposed mechanisms and there is growing evidence that a systemic inflammatory process may play a role in the development of POD $(4,5)$. Previous reports have also proposed that CAVD represents an inflammatory state of the valve interstitium similar to that seen in atherosclerosis and, even after TAVR, the inflammatory state persists in almost half of the patients $(6,7)$. As such, identifying accurate biomarkers for POD may shed light on the pathophysiology and potentially improve delirium recognition and prediction after TAVR. Several inflammatory markers, such as proinflammatory cytokines, chemokines, and the neutrophil-to-lymphocyte ratio (NLR), have been proposed to be associated with POD in various clinical conditions including cardiac surgery (8-10). In addition, although there are conflicting results, delirium has been found to be associated with proteins involved in the stress response, including the markers of systemic inflammation such as positive acute-phase reactant C-reactive protein (CRP) and negative acutephase reactant albumin $(2,4,5,11)$. Recently, a novel inflammatory marker defined as the CRP-to-albumin ratio (CAR) has been proposed as more valuable than either CRP or albumin alone in predicting inflammatory status and prognosis in various clinical settings $(12,13)$. To our knowledge, there are no data available regarding the association between CAR and POD in patients undergoing TAVR. Therefore, in this study, we sought to investigate the predictive value of CAR in determining POD development.

\section{Methods}

We performed a retrospective analysis of collected data of 81 consecutive patients, who underwent TAVR between January 2015 and March 2018, from the records of the cardiology department of our hospital. Data on patient demographics, comorbidities, primary cardiac acute illness, medical treatment, electrocardiogram, chest X-ray, echocardiogram, multislice computed tomography of the aorta and branches, cine coronary angiography, length of hospital stay, clinically significant in-hospital acute adverse events, Richmond agitation-sedation scale (RASS) score, Confusion Assessment Method for the Intensive Care Unit (CAM-ICU) score and mortality data were obtained using a computerised system and or patient file records or by way of follow-up visits of the patients. The exclusion criteria of the present study were as follows: patients undergoing combined procedures such as concurrent percutaneous coronary intervention, patients with an estimated life expectancy of less than one year, patients with a significant mental impairment, and concomitant inflammatory conditions (i.e., active infection, inflammatory arthritis, inflammatory bowel disease, or connective tissue disease) or malignancies, or those who had recent ( $<2$ months) surgery or major trauma. Of 81 patients, three patients were excluded; one $(1.3 \%)$ due to insufficient data two for having a history of cognitive impairment. Consequently, the study population consisted of 78 patients with a life expectancy of at least one year who were considered to be at high surgical risk for SAVR on the basis of clinical assessments by a multidisciplinary heart team $(2,3)$. Thirty-day and 37-month clinical follow-up data were obtained via outpatient visit or telephone contact. One hundred percent of patients adhered to the follow-up schedule after the index operation.

Severe aortic stenosis is defined as a valvular orifice area of less than $1.0 \mathrm{~cm}^{2}$ or less than $0.6 \mathrm{~cm}^{2} / \mathrm{m}^{2}$ and/or a mean pressure gradient of more than $40 \mathrm{mmHg}$ and/or a jet velocity of more than $4.0 \mathrm{~m} / \mathrm{s}$. The heart team used a guideline that was based on a risk model developed by the EurOSCORE II (ES II) to estimate the risk of death after the index TAVR procedure. ES II and Society of Thoracic Surgeons (STS)/American College of Cardiology (ACC) transcatheter valve therapy TAVR (TAVR score) scores were calculated using online tools (www.euroscore.org and https://tools.acc.org/tavrrisk).

The primary endpoint of this study was the presence of delirium on any day during the in-hospital stay after TAVR. Other clinical outcomes, such as all-cause mortality within 30 days, all-cause, cardiovascular, and noncardiovascular mortality after 30 days during follow-up, myocardial infarction, stroke, acute kidney injury (AKI), pacemaker requirement, life-threatening or disabling major bleeding, and major vascular complications, were adjudicated according to the Valvular Academic Research Consortium (VARC) criteria (14). 
The default access for TAVR was transfemoral and valve choice was decided at the discretion of the heart team. The procedure was performed in the cardiac catheterization laboratory under conscious sedation (mostly) or general anaesthesia with transesophageal echocardiography guidance. All patients received aspirin $(81 \mathrm{mg})$ and clopidogrel $(\geq 300 \mathrm{mg}$ ) before the procedure and heparin during the procedure; the patients continued to take aspirin indefinitely and clopidogrel for a minimum of one month. After the index procedure, all patients were followed up at 30 days, six and 12 months, and yearly thereafter. Written informed consent was not obtained from the participants due to retrospective nature of the study, but our study protocol conformed to the principles of the Declaration of Helsinki and was approved by the University of Health Sciences of Turkey, Haseki Training and Research Hospital Ethics Committee (no: 116/09.05.2019).

\section{Laboratory Measurements}

Routine complete blood cell count and blood evaluations for determining the blood glucose, creatinine, albumin, and CRP levels were performed using the admission blood samples. Serum albumin and CRP levels were measured by using a Roche Diagnostics Cobas 8000 c502 analyser (Roche Holding AG, Basel, Switzerland). CAR was calculated as the ratio of serum CRP level ( $\mathrm{mg} / \mathrm{L}$ ) to serum albumin level (mg/L) multiplied by 100 for easy interpretation, as done in previous studies (12). NLR was calculated by dividing the neutrophil count by the lymphocyte count. The estimated glomerular filtration rate (eGFR) was calculated by using the Modification of Diet in Renal Disease formula.

\section{Delirium Evaluation}

In our institution as part of routine care, all TAVR patients were screened for the presence of delirium using the RASS at admission and then once daily by coronary intensive care unit $(\mathrm{CICU})$ physicians and cardiovascular nurses (15). Presence of delirium was determined according to the CAM-ICU at admission and then if the RASS was -3 or greater to avoid inclusion of comatose/ unconscious patients (16).

The CAM-ICU value was considered positive for delirium if patients had a RASS score of -3 or greater and had an acute change or fluctuation in mental status plus inattention and either disorganized thinking or an altered level of consciousness. The patients were divided into two groups according to delirium status, i.e., delirious and nondelirious.

\section{Statistical Analysis}

Categorical variables are given as frequencies and percentages. The chi-square $\left(\chi^{2}\right)$ test was used to compare the categorical variables between the groups. Continuous variables were given as mean \pm standard deviation (if normal distribution) and medians (interquartile ranges) (if not normal distribution). The Kolmogorov-Smirnov test was used to assess whether the variables were normally distributed. The student's t-test or Mann-Whitney $U$ test was used to compare continuous variables between the groups according to whether they were normally distributed or not. In order to identify the independent preprocedural risk factors for POD, univariate and backward stepwise multivariable logistic regression analyses were performed. Only the variables with a $p$ value of less than 0.1 in univariate analysis were incorporated in the multivariate logistic regression analysis. Variables already included in the ACC/STS TAVR score and which exhibited excellent correlation with CAR and NLR were not considered separately in multivariable analysis, independently of their significance in univariable analysis. The receiver operating characteristics (ROC) curve analysis was used to evaluate the sensitivity and specificity of the CAR and its cut-off value for predicting POD. The association between POD and mortality was analysed using Kaplan-Meier curves created by delirium status and the long-rank test. The results were evaluated within a 95\% confidence interval $(\mathrm{Cl})$ and at a significance level of $p<0.05$. All statistical analyses were carried out using the Statistical Package for the Social Sciences version 24.0 (IBM Corp., Armonk, NY, USA).

\section{Results}

\section{Baseline Characteristics}

The median follow-up period was 18 [interquartile range (IQR): 10-25] months with a maximum of 37 months. The mean age was $76.3 \pm 8.4$ years and 46 (59\%) patients were female. The recorded admission diagnosis was heart failure in 53 (67.9\%), angina or angina-equivalent symptoms in 20 (25.6\%), and presyncope or syncope in five (6.4\%); none of the patients suffered sudden cardiac death. The mean aortic valve area (AVA) was $0.61 \pm 0.12$ $\mathrm{cm}^{2}$ and mean transvalvular gradient was $50.6 \pm 6.1 \mathrm{mmHg}$. Twenty-three (29.5\%) patients had severe symptoms defined as New York Heart Association (NYHA) classes III/ IV. Additionally, the mean ES II was $5.2 \pm 2.1 \%$ and TAVR risk score was $3.7 \pm 1.7 \%$.

The procedure was performed by using conscious sedation in $64(82.1 \%)$ patients or general anaesthesia in $14(17.9 \%)$ patients. Urgent procedures were performed in $18(23.1 \%)$ patients. Fifty-one (65.4\%) patients received a self-expandable valve, while 27 (34.6\%) received a balloon-expandable valve. Complications included new pacemaker insertion in $13(16.7 \%)$, any VARC2-defined major vascular injury in seven (9\%), major bleeding in $14(17.9 \%)$, and AKI in 10 (12.8\%) patients. 
Three (3.7\%) patients required dialysis treatment. None of the patients experienced myocardial infarction or permanent stroke or required surgical intervention periTAVR or post-TAVR. Detailed baseline demographic, and clinical, echocardiographic, pre- and post-procedural characteristics of the population are summarised in Table 1 and 2.

\section{Factors Associated with Postoperative Delirium}

In the present study, POD diagnosed using the CAM-ICU was observed in 17 (22\%) patients. Delirious patients had higher frequency of heart failure, severe chronic obstructive pulmonary disease (COPD), and NYHA classes III and IV than did non-delirious patients $(p=0.08, p=0.05$, and $p=0.07$, respectively), although not in a statistically significant fashion. Regarding blood examinations, serum CRP level $(p=0.007)$ and neutrophil count ( $p=0.04$ ) were higher in the delirious group, while serum albumin level was lower $(p=0.04)$. As compared with that in the non-delirious group, delirious patients also had significantly higher values of CAR $(p=0.006)$. NLR value was also found to be higher in delirious patients, but this finding had borderline statistical significance $(p=0.06)$. According to echocardiographic examination, AVA and mean aortic valve gradient were not different between the two groups. Besides that, left ventricular ejection fraction (LVEF) was lower $(p=0.03)$, whereas pulmonary artery systolic pressure was higher $(p<0.001)$ in delirious patients than in the others. eGFR was also found to be lower in those suffering from POD $(p=0.04)$. When considering the procedural risk assessment scoring systems, ES II and TAVR score were significantly higher in the delirious group than in the non-delirious group $(p=0.03$ and $p=0.009$, respectively). Additionally, major bleeding, major vascular complications, and AKI were more frequent in patients with POD $(p=0.005, p=0.018$, and $p=0.002$, respectively).

\begin{tabular}{|c|c|c|c|c|}
\hline Variables & All population & $\begin{array}{l}\text { No Delirious } \\
(n=61)\end{array}$ & \begin{tabular}{|l} 
Delirious \\
$(\mathrm{n}=17)$
\end{tabular} & $p$ \\
\hline Female gender & $46(59)$ & $37(60.7)$ & $9(52.9)$ & 0.57 \\
\hline Age, years & $76.3 \pm 8.4$ & $75.7 \pm 8.7$ & $78.7 \pm 6.8$ & 0.19 \\
\hline Hypertension & $52(66.7)$ & 39 (63.9) & $13(76.5)$ & 0.3 \\
\hline Diabetes Mellitus & $25(32.1)$ & $17(27.9)$ & $8(47.1)$ & 0.1 \\
\hline Heart failure & $36(46.2)$ & $25(41)$ & $11(64.7)$ & 0.08 \\
\hline Vascular disease & $38(48.7)$ & $29(47.5)$ & $9(52.9)$ & 0.69 \\
\hline CVA history & $7(9)$ & $4(6.6)$ & $3(17.6)$ & 0.16 \\
\hline CKD history & $25(32.1)$ & $16(26.2)$ & $9(52.9)$ & 0.04 \\
\hline COPD & $26(33.3)$ & $17(27.9)$ & $9(52.9)$ & 0.05 \\
\hline NYHA Class III-IV & $23(29.5)$ & $15(24.6)$ & $8(47.1)$ & 0.07 \\
\hline Atrial fibrillation & $16(20.5)$ & $12(19.7)$ & $4(23.5)$ & 0.7 \\
\hline Presence of BBB & $17(21.8)$ & $13(21.3)$ & $4(23.5)$ & 0.9 \\
\hline FBG, $\mathrm{mg} / \mathrm{dL}$ & $141 \pm 63.2$ & $138 \pm 59.6$ & $151.8 \pm 75.9$ & 0.43 \\
\hline eGFR, $\mathrm{mL} / \mathrm{min} / 1.73 \mathrm{~m}^{2}$ & $66.7 \pm 24.4$ & $69.6 \pm 23.7$ & $56.2 \pm 24.4$ & 0.04 \\
\hline CRP, mg/L & $5.5(2.2-11.4)$ & $4.4(2.0-9.1)$ & $9.55(5.5-18.5)$ & 0.007 \\
\hline Albumin, $\mathrm{g} / \mathrm{L}$ & $38(33.3-40)$ & $39(34.8-41.3)$ & $34(30.9-39.5)$ & 0.04 \\
\hline CAR, $(x 100)$ & $14.8(5.3-32.3)$ & $11.8(4.8-26.8)$ & 29.5 (14.5-59) & 0.006 \\
\hline Hematocrit, \% & $35.5 \pm 4.5$ & $35.9 \pm 4.4$ & $34.1 \pm 4.7$ & 0.15 \\
\hline Neutrophil, $10^{3} / \mu \mathrm{L}$ & $4.7(3.4-7.1)$ & $4.3(3.3-6.1)$ & $7.1(3.9-12.1)$ & 0.04 \\
\hline Lymphocyte, $10^{3} / \mu \mathrm{L}$ & $1.62(1.2-2.2)$ & $1.61(1.2-2.2)$ & $1.64(0.98-2.1)$ & 0.8 \\
\hline NLR & $2.9(2.1-4.8)$ & $2.63(2.1-3.9)$ & $4.0(2.4-9.2)$ & 0.06 \\
\hline TAVR score, $\%$ & $3.7 \pm 1.7$ & $3.4 \pm 1.5$ & $4.9 \pm 1.8$ & 0.009 \\
\hline Euroscore II, \% & $5.2 \pm 2.1$ & $4.9 \pm 2.0$ & $6.1 \pm 2.1$ & 0.03 \\
\hline \multicolumn{5}{|c|}{$\begin{array}{l}\text { CVA: Cerebrovascular accident, CKD: Chronic kidney disease, COPD: Chronic obstructive pulmonary disease, NYHA; New York Heart Association, BBB: Bundle branch } \\
\text { block, FBG: Fasting blood glucose, eGFR: Estimated glomerular filtration rate, CRP: C-reactive protein, CAR: CRP to albümin ratio, NLR: Neutropil to lymhocyte ratio, TAVR: } \\
\text { Transcatheter aortic valve replacement, } n \text { : Number } \\
\text { Values are } \mathrm{n}(\%) \text {, median (interquartile range), or mean } \pm \text { standart deviation }\end{array}$} \\
\hline
\end{tabular}




\section{Independent Predictors of Postoperative Delirium}

In order to determine the independent predictors of $\mathrm{POD}$, we performed multivariable logistic regression analysis by incorporating variables that showed statistically significant associations in the univariate analysis. CRP and neutrophil were not included in the regression analysis because of excellent correlation between CAR and CRP $(r=0.983 ; p<0.001)$ and between neutrophil and NLR $(r=0.718 ; p<0.001)$, but albumin was included since it exhibited a moderate correlation with CAR ( $r=-0.467$; p 0.001 ). In addition, ES II was not included in the multivariable regression analysis because it encompasses many POD-related parameters such as creatinine clearance, pulmonary artery pressure, LVEF, NYHA class, and COPD and is also not a TAVR-specific scoring system. Conversely, because the TAVR score contains relatively less PODrelated variables and is a TAVR-specific scoring system, it was included in the multivariate regression analysis. In the multivariable analysis, postoperative AKI $(p=0.02)$, major bleeding $(p=0.005)$, TAVR score $(p=0.04)$, and CAR $(p=0.02)$ were found to be independent predictors for the development of POD (Table 3). To test the predictive performance of CAR, we performed ROC curve analysis. The area under the curve of CAR for POD development was 0.718 (95\% Cl: $0.605-0.814 ; p=0.002)$ with a cutoff value of greater than 13 (82\% sensitivity and 56\% specificity) (Figure 1).

\section{Postoperative Delirium and Overall Survival}

At 30 days and 37 months, the mortality rate was higher in the delirious group than in the nondelirious one $(p=0.002$ and $p<0.001$, respectively). POD was significantly associated with short-term ( $\leq 30$ days) [ $p=0.009$; hazard ratio (HR): $0.186 ; 95 \% \mathrm{Cl}: 0.052-0.658$ ] and late mortality ( $p<0.001$; HR: 0.193; 95\% Cl: 0.088-0.422) after TAVR in univariate Cox regression analysis. The association between POD and mortality is depicted by Kaplan-Meier plots of survival curves in Figure 2.

\section{Discussion}

The main findings of the present study are as follows: 1) POD is common after TAVR and occurs in about onefifth of patients; 2) higher preoperative CAR values, procedure-related major bleeding, postoperative AKI, and TAVR score are independently associated with the

\begin{tabular}{|c|c|c|c|c|}
\hline Variables & All population & $\begin{array}{l}\text { No delirium } \\
(\mathrm{n}=61)\end{array}$ & $\begin{array}{l}\text { Delirium } \\
(\mathrm{n}=17)\end{array}$ & $p$ \\
\hline AVA, $\mathrm{cm}^{2}$ & $0.61 \pm 0.12$ & $0.63 \pm 0.13$ & $0.58 \pm 0.12$ & 0.16 \\
\hline Mean AVG, mmHg & $50.6 \pm 6.1$ & $50.1 \pm 6.2$ & $52.4 \pm 5.4$ & 0.19 \\
\hline LVEF, \% & $47.8 \pm 8.3$ & $48.9 \pm 8$ & $43.8 \pm 8.4$ & 0.03 \\
\hline PAPs, $\mathrm{mmHg}$ & $49 \pm 9.8$ & $47.1 \pm 9.3$ & $55.8 \pm 9.0$ & $<0.001$ \\
\hline Urgent procedure & $18(23.1)$ & $10(16.4)$ & $8(47.1)$ & 0.008 \\
\hline Conscious sedation & $64(82.1)$ & $51(83.6)$ & $13(76.5)$ & 0.5 \\
\hline Type of valve & - & - & - & 0.2 \\
\hline Self-expandable & $51(65.4)$ & $42(68.9)$ & $9(52.9)$ & - \\
\hline Balloon-expandable & $27(34.6)$ & $19(31.1)$ & $8(47.1)$ & - \\
\hline Predilatation & $36(46.2)$ & $27(44.3)$ & $9(52.9)$ & 0.5 \\
\hline Postdilatation & $14(17.9)$ & $11(18)$ & $3(17.6)$ & 0.97 \\
\hline Major bleeding & $14(17.9)$ & $7(11.5)$ & $7(41.2)$ & 0.005 \\
\hline Acute kidney injury & $10(12.8)$ & $4(6.6)$ & $6(35.3)$ & 0.002 \\
\hline Major vascular complications & $7(9)$ & $3(4.9)$ & $4(23.5)$ & 0.018 \\
\hline Permanant pacemaker & $13(16.7)$ & $12(19.7)$ & $1(5.9)$ & 0.18 \\
\hline Myocardial infarction & $0(0)$ & $0(0)$ & $0(0)$ & - \\
\hline Stroke & $0(0)$ & $0(0)$ & $0(0)$ & - \\
\hline Hospitalization, days & $6(4-8)$ & $5(4-7)$ & $10(6-12.5)$ & $<0.001$ \\
\hline Rehospitalization & $14(17.9)$ & $9(14.8)$ & $5(29.4)$ & 0.16 \\
\hline Early mortality ( $\leq 30$ days) & $10(12.8)$ & $4(6.6)$ & $6(35.3)$ & 0.002 \\
\hline Late mortality (>30 days) & $26(33.3)$ & $13(21.3)$ & $13(76.5)$ & $<0.001$ \\
\hline
\end{tabular}


development of POD, while NLR is not; 3) a CAR value of greater than 13 is a predictor of POD development; and 4) POD is significantly related with both early and late overall mortality.

In accordance with the literature, the incidence of POD on the basis of the CAM-ICU criteria was $22 \%$ in the current study cohort $(3,17,18)$. In comparison, the incidence of delirium in the existing literature ranges from $12 \%$ to $53 \%$ after TAVR (18). This variation in the POD incidence may in part be due to the lack of frequent assessments, different assessment methods of delirium (e.g., medical records, diagnosis codes), and a lack of standardised criteria for diagnosis (19).

Although no consensus regarding the risk factors for POD has yet been established, probably due to its complicated pathogenesis, a number of predisposing

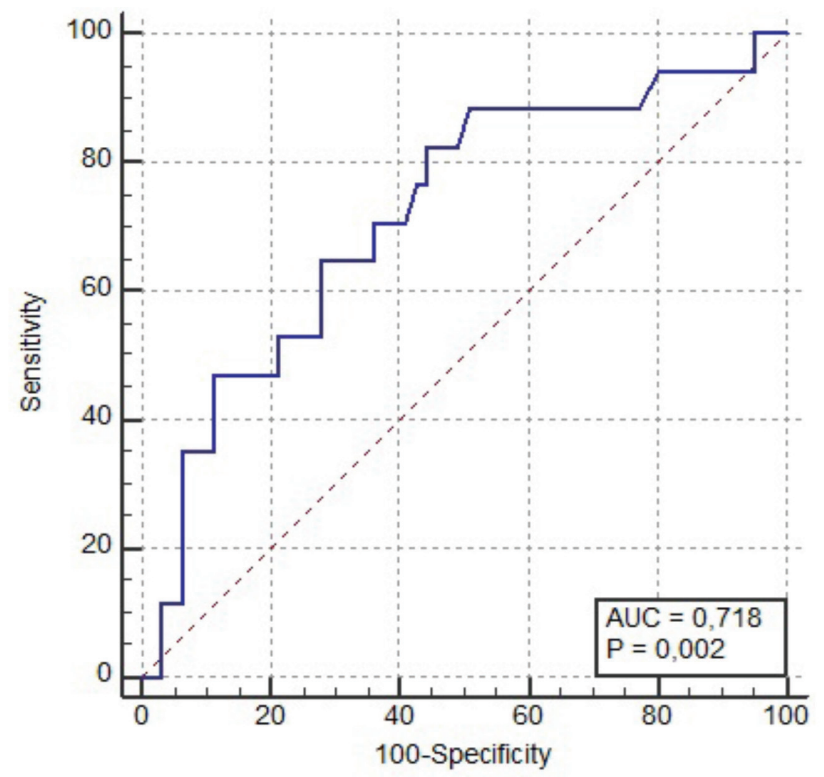

Figure 1. ROC curves of the C-reactive protein to albumin ratio for prediction the postoperative delirium development

ROC: Receiver operative characteristics, AUC: Area under the curve
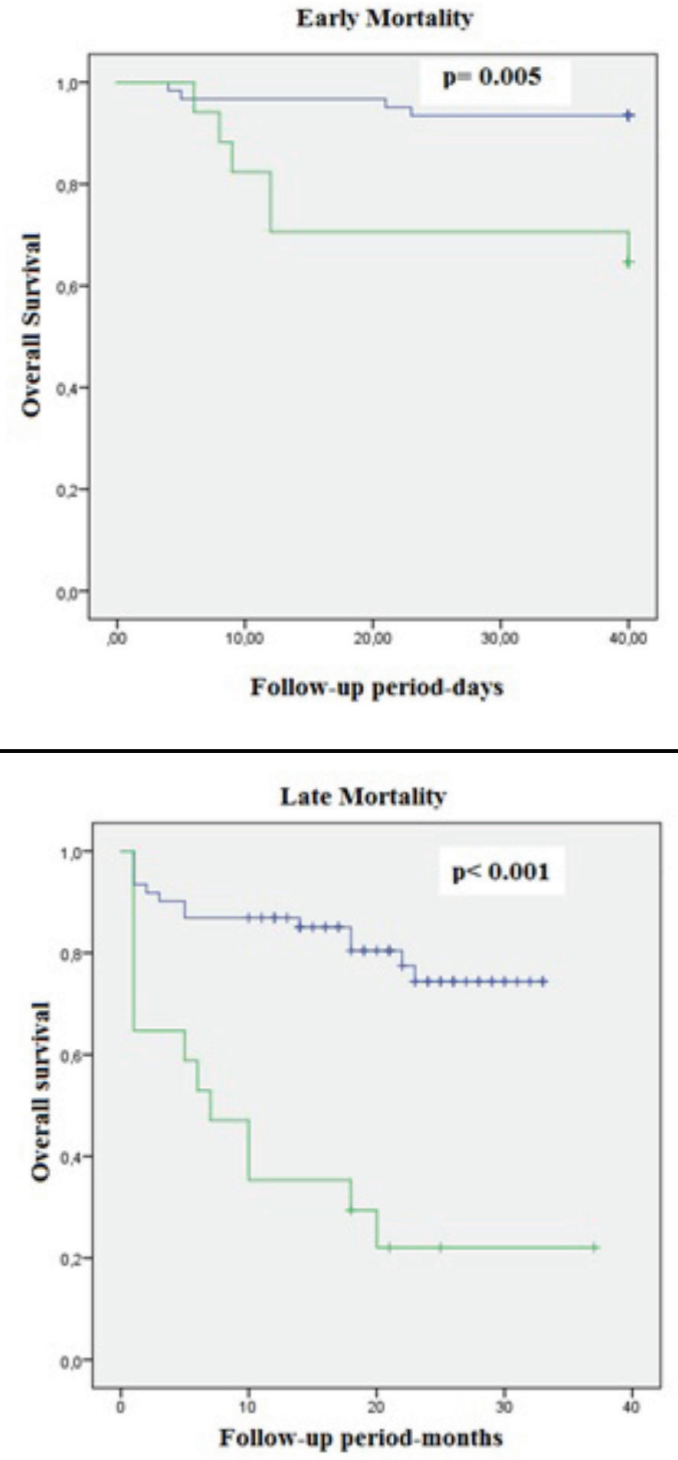

Figure 2. Kaplan-Meier plots of survival curves of deliriuos and no delirious patients

\begin{tabular}{|c|c|c|c|c|}
\hline \multirow[t]{2}{*}{ Variables } & \multicolumn{2}{|l|}{ Univariable } & \multicolumn{2}{|l|}{ Multivariable } \\
\hline & OR (95\% Cl) & $\mathbf{p}$ & OR (95\% Cl) & $\mathbf{p}$ \\
\hline AKI & $0.129(0.031-0.532)$ & 0.005 & $0.136(0.024-0.765)$ & 0.02 \\
\hline Major bleeding & $0.185(0.053-0.644)$ & 0.008 & $0.080(0.014-0.466)$ & 0.005 \\
\hline CAR & $1.027(1.005-1.049)$ & 0.015 & $1.039(1.006-1.073)$ & 0.02 \\
\hline LVEF & $0.928(0.868-0.994)$ & 0.03 & $1.041(0.940-1.154)$ & 0.44 \\
\hline COPD & $0.343(0.114-1.037)$ & 0.06 & $0.279(0.064-1.212)$ & 0.09 \\
\hline TAVR score & $1.706(1.219-2.387)$ & 0.002 & $1.621(1.033-2.541)$ & 0.04 \\
\hline
\end{tabular}

AKI: Acute kidney injury, CAR: CRP to albumin ratio, LVEF: Left ventricular ejection fraction, COPD: Chronic obstructive pulmonary disease, TAVR: Transcatheter aortic valve replacement, OR: Odds ratio, $\mathrm{Cl}$ : Confidence interval 
and precipitating risk factors have been identified to date $(3,11,20)$. Predisposing factors, such as age, physical status, previous vascular disease, prior stroke, hypertension, diabetes, atrial fibrillation, NYHA classes III and IV, COPD, LVEF, and ES, are generally nonmodifiable and characterise a person's susceptibility to developing delirium, while precipitating factors, like medications, major surgery, TAVR, infectious disease, AKI, bleeding, and metabolic alterations, are modifiable items that trigger the onset of delirium (3,20-22). In the current study, none of these aforementioned predisposing risk factors, such as stroke, hypertension and COPD, were found to be predictors. To the best of our knowledge, there is no evidence to assess the relationship between TAVR score and delirium. In this study, among the predisposing factors, only TAVR score was found to be a predictor of the development of POD. On the other hand, among the precipitating factors, procedure-related AKI and bleeding were found to be independent predictors of POD development, in line with previous reports $(20,21)$. Although there is no established protocol for the prevention of periprocedural $A K I$, adequate hydration and avoidance of nephrotoxic medications may constitute preventative therapy. In addition, a previous study showed that anemia increases the risk of POD, whereas a blood transfusion reduces its incidence (23). So, the incorporation of blood transfusions might prevent POD in patients after TAVR.

Despite the condition's observed high prevalence and negative effect on outcomes, the pathophysiology of POD remains unclear $(4,9,22)$. Previous reports have proposed that systemic inflammation contributes to the pathogenesis of POD by compromising blood-brain barrier integrity and consequently promoting neuronal injury, causing neurocognitive behavioural abnormalities $(4,5,9)$. Several immune and inflammatory alterations such as increased acute-phase reactants and abnormal levels of inflammatory cytokines detected in both the serum and cerebrospinal fluid of delirious individuals have been reported in the literature $(4,8-11,24)$. Therefore, the identification of inflammatory markers associated with POD can improve our understanding of POD pathophysiology and ultimately leads to new interventions that may improve patient outcomes.

CRP, one of the most common markers for systemic inflammation, has been linked with increased cardiovascular and allcause mortality following TAVR $(25,26)$. In addition, although there are conflicting data, the previous literature sought to examine the relationship between pre- and postoperative elevated CRP levels and the development of POD in patients undergoing cardiac and noncardiac surgery $(2,27,28)$. In the present study, because of its excellent correlation with CAR, we did not analyse the predictive value of preoperative plasma CRP level in determining POD, but did note that baseline CRP levels were higher in delirious patients than in non-delirious ones. The association of preoperative hypoalbuminemia with the development of POD has also been reported in various surgical populations $(11,28,29)$. This relationship can be explained by several mechanisms, such as reduced transport of delirogenic medication with consequent increased risks of side effects and drug activity. Second, hypoalbuminemia is an important indicator of the acute-phase reaction and activation of the immune system. Therefore, patients with POD have a stronger acute-phase reaction and activation of the immune system followed by an increasingly damaging cytokine influence on the transmitter systems of the central nervous system (29). CAR is a novel inflammatory parameter and was first described by Fairclough et al. (12). CAR contains both CRP and albumin parameters and reflects not only the proinflammatory state, but also the nutritional status. Therefore, the combination of albumin and CRP in a single index may be more valuable and provide both inflammatory and nutritional information. In addition, this combination as a prognostic score provides stability between fluctuating CRP and albumin levels in diseases where inflammation plays an important role (30). Considering these aforementioned reasons, the combination of albumin and CRP in a single index has previously been proposed and subsequent studies have shown that the CAR was more sensitive and specific in the prediction of the systemic inflammatory state and prognosis than either serum CRP or albumin level alone in various clinical conditions $(12,13,30,31)$. To our knowledge, this is the first study evaluating the association between CAR and the development of POD in patients who underwent transfemoral TAVR. In the current study, we observed that delirious patients had higher preoperative CAR values, and CAR values of more than 13 were found to be predictive of POD development. We know that CAVD is the most common valvular heart disease in the elderly and inflammation plays an important role in the development and progression of CAVD, with similarities to atherosclerosis (32). In addition, there is also increasing evidence that aging is associated with increased basal neuroinflammation that manifests as increased levels of activated microglia, the immune cells of the brain (33). As a result, higher CAR values may be an indicator of this basal inflammatory condition, which may have a priming effect, leading to an increased response to peripheral stimuli such as surgery (34).

NLR, another inflammatory marker, has been reported to serve as a valuable indicator of systemic inflammation 
in comparison with traditional markers such as total white blood cell (WBC) count, individual WBC subtypes, and CRP in various clinical conditions $(24,35)$. NLR has been investigated in the context of neuropsychiatric disorders such as cerebrovascular disease, schizophrenia, and Alzheimer's disease to quantify the systemic inflammation in these disorders (24). Egberts and Mattace-Raso (24) in their study observed increased NLR levels in delirious patients and suggested that an inadequate response of the immune system and oxidative stress may play a role in the pathogenesis of delirium. To the best our knowledge, no previous study has investigated a possible association between NLR and POD in patients who underwent TAVR. Although preprocedural NLR is higher in patients with delirium, contrary to Egberts and Mattace-Raso (24), we have not observed any relationship between NLR and delirium. Furthermore, some previous studies have suggested that CAR was superior to NLR in predicting systemic inflammation and prognosis in several cardiac and noncardiac conditions $(36,37)$.

In line with previous data, in the current study, POD after TAVR was significantly associated with increased early and late mortality $(3,38)$. However, the real question to be asked here is whether or not the increases in mortality and morbidity can really be attributed to POD. Rather than being causally related with mortality, POD may reflect a patient's decreased resilience against noxious stimuli (i.e., their fragility) and thus merely identify the individuals who are already predisposed to worse treatment outcomes.

Nonpharmacological strategies reduce the incidence of delirium by $30 \%$ to $40 \%$ (3). As such, knowledge of the predictive factors for POD is very important for identifying patients who are at increased risk and who are most likely to benefit from preventive measures such as proactive interdisciplinary collaboration, geriatrics consultation, rehabilitation, nonpharmacologic sleep protocols, early mobilization, sensory aids, minimization of psychoactive medication usage, and intensified postoperative monitoring $(3,19)$.

\section{Study Limitations}

Our study has some limitations that should be noted. First, our investigation was a retrospective registry analysis involving a small number of consecutive patients who underwent TAVR at a single centre. Since our patient number was relatively small, this study may be underpowered to detect the predictive value of CAR upon POD development. Second, the retrospective assessment of delirium may have led to an underestimation of the incidence of POD. Third, our analysis is retrospective regarding early and late mortality; in particular, we could not assess long-term cognitive impairment. Fourth, although this study points to CAR as a new risk factor for POD development, the mechanism by which it operates is still not clear. Thus, large-scale prospective studies are needed to validate the predictive value of preoperative CAR in determining POD occurrence after TAVR.

\section{Conclusion}

Our findings suggest an independent role of CAR in delirium above and beyond conventional inflammatory markers. From a clinical standpoint, we think that preoperative CAR is a novel and promising predictive inflammatory parameter for the development of POD and may help the physician with identifying subgroups of individuals at risk for POD to guide the deployment of preventive strategies before TAVR. Our findings also support the important role of inflammation in the pathophysiology of delirium and can shed light on development of new pathophysiologically based intervention strategies to prevent and/or treat this clinically important issue.

\section{Authorship Contributions}

Concept: M.K. Design: M.K., H.I.B. Data Collection or Processing: M.K., H.I.B., B.B. Analysis or Interpretation: M.K., B.B., M.M.C. Literature Search: M.K., H.I.B., G.D. Writing: M.K.

Conflict of Interest: No conflict of interest was declared by the authors.

Financial Disclosure: The authors declared that this study received no financial support.

\section{References}

1. Nishimura RA, Otto CM, Bonow RO, Carabello BA, Erwin JP 3rd, and et al. 2014 AHA/ACC guideline for the management of patients with valvular heart disease: a report of the American College of Cardiology/American Heart Association Task Force on Practice Guidelines. J Thorac Cardiovasc Surg 2014; 148:e1-132.

2. Liu $X, Y u$ Y, Zhu S. Inflammatory markers in postoperative delirium (POD) and cognitive dysfunction (POCD): A meta-analysis of observational studies. PLoS One. 2018;13:e0195659.

3. Abawi M, Nijhoff F, Agostoni P, et al. Incidence, Predictive Factors, and Effect of Delirium After Transcatheter Aortic Valve Replacement. J Am Coll Cardiol Intv 2016;9:160-8.

4. Vasunilashorn SM, Dillon ST, Inouye SK, et al. High C-reactive Protein Predicts Delirium Incidence, Duration, and Feature Severity after Major Non-cardiac Surgery. J Am Geriatr Soc 2017;65:e109-16.

5. Simone MJ, Tan ZS. The role of inflammation in the pathogenesis of delirium and dementia in older adults: a review. CNS Neurosci Ther 2011;17:506-13.

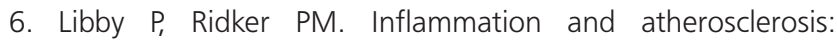
role of C-reactive protein in risk assessment. Am J Med 2004;116(Suppl 6A):9S-16S. 
7. Gerber I, Stewart R, Hammett C, et al. Effect of aortic valve replacement on $\mathrm{C}$-reactive protein in nonrheumatic aortic stenosis. Am J Cardiol 2003;92:1129-32.

8. Androsova $G$, Krause $R$, Winterer $G$ and Schneider $R$. Biomarkers of postoperative delirium and cognitive dysfunction. Frontiers in Aging Neuroscience 2016;7:112.

9. Rudolph JL, Ramlawi B, Kuchel GA, McElhaney JE, Xie D, Sellke FW, et al. Chemokines are associated with delirium after cardiac surgery. J Gerontol A Biol Sci Med Sci 2008;63:184-9.

10. Theologou S, Giakoumidakis K, and Charitos C. Perioperative predictors of delirium and incidence factors in adult patients post cardiac surgery. Pragmat Obs Res 2018;9:11-9.

11. Zhang DF, Su X, Meng ZT, et al. Preoperative severe hypoalbuminemia is associated with an increased risk of postoperative delirium in elderly patients: Results of a secondary analysis. J Crit Care 2018;44:45-50.

12. Fairclough E, Cairns E, Hamilton J, Kelly C. Evaluation of a modified early warning system for acute medical admissions and comparison with C-reactive protein/ albumin ratio as a predictor of patient outcome. Clin Med 2009;9:30-3.

13. Cağdaş M, Rencüzoğullari I, Karakoyun S, et al. Assessment of Relationship Between C-Reactive Protein to Albumin Ratio and Coronary Artery Disease Severity in Patients With Acute Coronary Syndrome. Angiology 2019;70:361-8.

14. Kappetein AP, Head SJ, Généreux P, et al. Valve Academic Research Consortium (VARC)-2. Updated standardized endpoint definitions for transcatheter aortic valve implantation: the Valve Academic Research Consortium-2 consensus document (VARC-2). J Am Coll Cardiol 2012;60:1438-54

15. Ely EW, Truman B, Shintani A, et al. Monitoring sedation status over time in ICU patients: reliability and validity of the Richmond Agitation-Sedation Scale (RASS). JAMA 2003;289:2983-91.

16. Ely EW, Margolin R, Francis J, et al. Evaluation of delirium in critically ill patients: validation of the Confusion Assessment Method for the Intensive Care Unit (CAM-ICU). Crit Care Med 2001;29:1370-9.

17. Tse L, Bowering JB, Schwarz SK, Moore RL, Burns KD, Barr AM. Postoperative delirium following transcatheter aortic valve implantation: a historical cohort study. Can J Anaesth 2015;62:22-30.

18. Assmann P, Kievit P, van der Wulp K, Verkroost M, Noyez L, Bor $\mathrm{H}$, et al. Frailty is associated with delirium and mortality after transcatheter aortic valve implantation. Open Heart 2016;3:e000478.

19. Shi SM, Sung M, Afilalo J, Lipsitz LA, Kim CA, Popma JJ, et al. Delirium Incidence and Functional Outcomes After Transcatheter and Surgical Aortic Valve Replacement. J Am Geriatr Soc 2019;67:1393-1401.
20. Tilley E, Psaltis PJ, Loetscher T, et al. Meta-analysis of Prevalence and Risk Factors for Delirium After Transcatheter Aortic Valve Implantation. Am J Cardiol 2018;122:1917-23.

21. Stachon P, Kaier K, Zirlik A, et al. Risk factors and outcome of postoperative delirium after transcatheter aortic valve replacement. Clin Res Cardiol 2018;107:756-62.

22. Prasitlumkum N, Mekritthikrai R, Kewcharoen J, Kanitsoraphan C, Mao MA, Cheungpasitporn W. Delirium is associated with higher mortality in transcatheter aortic valve replacement: systemic review and meta-analysis. Cardiovasc Interv Ther 2019, doi: 10.1007/s12928-019-00592-y.

23. van der Zanden V, Beishuizen SJ, Scholtens RM, de Jonghe A, de Rooij SE, van Munster BC. The effects of blood transfusion on delirium incidence. J Am Med Dir Assoc 2016;17:748-53.

24. Egberts A, Mattace-Raso FU. Increased neutrophil-lymphocyte ratio in delirium: a pilot study. Clin Interv Aging 2017;12:111521.

25. Ruparelia N, Panoulas VF, Frame A, et al. Impact of clinical and procedural factors upon $C$ reactive protein dynamics following transcatheter aortic valve implantation. World J Cardiol 2016;8:425-31.

26. Do U, Ahn JM, Kang DY, Ko E, et al. Association and Prognostic Implication of C-Reactive Protein with Risk of 1-Year Death or Disabling Stroke After Transcatheter Aortic Valve Replacement. Structural Heart 2019;4:312-20.

27. Dillon ST, Vasunilashorn SM, Ngo L, et al. Higher C-reactive Protein Levels Predict Postoperative Delirium in Older Patients Undergoing Major Elective Surgery: A Longitudinal Nested Case-Control Study. J Int Med Res 2016;44:317-27.

28. Ayob F, Lam E, Ho G, Chung F, El-Beheiry H, Wong J. Preoperative biomarkers and imaging tests as predictors of post-operative delirium in non-cardiac surgical patients:a systematic review. BMC Anesthesiol 2019;19:25.

29. Baranyi A, Rothenhäusler HB. The impact of intra- and postoperative albumin levels as a biomarker of delirium after cardiopulmonary bypass: Results of an exploratory study. Psychiatry Res 2012;200:957-63.

30. Rencuzogullari I, Karabağ Y, Çağdaş $M$, et al. Assessment of the relationship between preprocedural C-reactive protein/ albumin ratio and stent restenosis in patients with STsegment elevation myocardial infarction. Rev Port Cardiol 2019;38:269-77.

31. Park JE, Chung KS, Song JH, Kim SY, Kim EY, et al. The C-Reactive Protein/Albumin Ratio as a Predictor of Mortality in Critically III Patients. J Clin Med 2018;7. pii: E333.

32. Sanchez PL and Mazzone AM. C-reactive protein in degenerative aortic valve stenosis. Cardiovasc Ultrasound 2006;4:24.

33. Simone MJ, Tan ZS. The role of inflammation in the pathogenesis of delirium and dementia in older adults: a review. CNS Neurosc Ther 2011;17:506-13. 
34. Godbout JP, Chen J, Abraham J, et al. Exaggerated neuroinflammation and sickness behavior in aged mice following activation of the peripheral innate immune system. FASEB J 2005;19:1329-31.

35. Guthrie GJ, Charles KA, Roxburgh CS, Horgan PG, McMillan DC, Clarke SJ. The systemic inflammation-based neutrophillymphocyte ratio: experience in patients with cancer. Crit Rev Oncol Hematol 2013;88:218-30.

36. Xu H, Hu L, Wei X, Niu J, Gao Y, He J, Hou J. The Predictive Value of Preoperative High-Sensitive C-Reactive Protein/
Albumin Ratio in Systemic Inflammatory Response Syndrome After Percutaneous Nephrolithotomy. J Endourol 2019;33:18.

37. Çınar T, Cağdas M, Rencüzoğulları I, et al. Prognostic efficacy of C-reactive protein/albumin ratio in ST elevation myocardial infarction. Scand Cardiovasc J 2019:1-8.

38. Witlox J, Eurelings LS, de Jonghe JF, Kalisvaart KJ, Eikelenboom $P$, van Gool WA. Delirium in elderly patients and the risk of postdischarge mortality, institutionalization, and dementia: a meta-analysis. JAMA 2010;304:443-51. 